\title{
To Study the Effects of Different Packaging Materials on Shelf Life of Sapota - A Review
}

\author{
Joseph K. Beikhosia* and Vijaya Rawat \\ School of Agriculture, Lovely Professional University, Punjab, India \\ *Corresponding author
}

\begin{abstract}
A B S T R A C T
The sapota fruit is very perishable cannot store longer than 5 days to rapid metabolic activities. Sapota fruit was reported massive post harvest losses and need mandatory to increase the shelf life of Sapota 20-30 days accordingly, there's a essential to control its ripening .. With none treatment, these could also be spoiled and to loss of water from fruit surface, faster respiration rate, attack of microorganisms, developing physiological disorders needed Modification of the atmosphere inside the package by lowering $\mathrm{O} 2$ concentration and increasing $\mathrm{CO} 2$ concentration depends on the characteristics of the produce and therefore the sort of the packaging film L-49 were wrapping using $9 \mu$ LLDPE film result shown successfully stored up to 12 days at diffusive. And in evaporative cool chamber18 days with insignificant loss in vitamin C content $25-30 \%$ By applying T3 (shrink), the shelf life of fruit is increased for several time period at optimized temperatures $\left(13-15^{\circ} \mathrm{C}\right) 75 \mu \mathrm{LDPE}$ (T2) proved to be the best treatments according to results revealed and followed by $100 \mu \mathrm{LDPE}$ (T3) also reported improve the quality standard and storability of fruits the $75 \mu \mathrm{LDPE}$ (T3 .As recorded in PP non-perforated The storage can increase upto 15 days and PP non-perforated $(0.025 \mathrm{~mm})$ was recorded as the most positive effect in physiological and maintain the chemical content like TSS and increase the shelf life for several days at rotating state using with 110C in $25 \mu$ LDPE bags fruit was stored up to 35 days the treatment T3 (Shrink) showed result as compared to other treatments. In the T3 treatment, the shelf life of fruit increases to 18 days but in the other treatments the shelf life was only 15 days. The fruit without any treatments was edible around 6 days only. The minimum physiological loss in weight, decay loss and maximum pulp: peel ratio, fruit shape By applying T3 (shrink), enhance temperatures (13$15^{\circ} \mathrm{C}$ ) the shelf life of fruit is increased for some time.
\end{abstract}

Keywords

(MAP)

Modification of the atmosphere LDPE, HDPE, Shrinkfilm, Polypropylene and Cling

Article Info

Accepted: 17 October 2020 Available Online: 10 November 2020

\section{Introduction}

Sapota (Acharus zapota L.) it's a tropical crop and may be grown up to an altitude of 1000 meters. It are often grown altogether sorts of soils a fruit bearing tree belong to the Sapotaceae comprises about 70 genera and
800 species which incorporates trees or shrubs out of which genus Acharus comprises 85 species belongs to tropical and warmtemperate, fruit-bearing plants basic chromosome number of sapota is 7 but varies from 9-13.Native to South-East Mexico and other countries it's commercially grown for 
the assembly of chickle, which may be a gum like substance obtained from latex and is especially used for preparation of chewing gum. In India, cultivation Sapota was started first time in Gholwad, a village in Maharashtra in 1898 (Cheema et al., 1954). In Gujarat, Andhra Pradesh, Karnataka Maharashtra Punjab and Haryana. And Orissa states sapota is grown commercially about 120740 hectare and 14.57 lakh tonne (NHB, 2016).

The sapota fruit is extremely perishable cannot store longer than 5 days to rapid metabolic activities, sapota fruit was reported from massive post harvest losses (Salunkhe, D. K. and B, Desai) Post harvest biotechnology of fruits, vol.1, $168 \mathrm{pp}$. (CRC presses Florida, U.S.A 1984). During harvesting, post-harvest activities about Rs. 70,000 crores as fruit play great significance role in human nutrition (Chundawat, 1998) Sapota, Agrotech Publishing (Academd, Udarpur, India). Therefore, there's a specification to manage its ripening so on improve the shelf life period. With none treatment, these could also be spoiled and to loss of water from fruit surface, faster respiration rate, attack of microorganisms, developing physiological disorders. To minimize the post harvest losses and to fulfill this requirement a study was conducted the consequences of various packaging materials to enhance the time period on Sapota, fruits uses of the polythene bags (Kariyanna and Reddy 1993) concluded that the rise in time period by using polyethylene wrap reported improvement in wound healing as well as it increase the shelf life of sopotafruit . Separately Sealing fruit in $0.015 \mathrm{~mm}$ thick (HDPE) was reported the weight loss of sapota fruit and under unrestrained in normal conditions. HDPE wrapped fruit keep magnificent external and even internal qualities for several days with the help of packaging material like polyethylene packaging, As reported the CFB packages and other materials like wax or coating effect in maintained the fruit physiology and reducing the loss. Ber fruit also reported can increase the shelf life of ber fruit up to 15 days the quality of Ber can maintain without any loss as well as in cool chamber it was reported and extended up to 29 days. Wax treatment including polythene and shrink as reported polyethylene film with the help of ethylene absorbent preserved the fruit quality without loss for 44-45 days (Rajesh Kumar et al., 2012). Fresh fruits after their harvest, still consuming oxygen $\left(\mathrm{O}_{2}\right)$ and giving off carbon dioxide $\left(\mathrm{CO}_{2}\right)$. During the method, carbohydrates stored within the tissues of the commodities are utilized and energy within the sort of heat is released. Decreasing $\mathrm{O}_{2}$ level and increasing $\mathrm{CO}_{2}$ level reduces the respiration rate, with the advantage of delaying senescence and browning, reducing metabolic activity, maintaining color, lowering microbial proliferation, and reducing chilling injury symptoms, thus, extends the time period of the merchandise (Beaudry, 1999) (Brecht et al., 2003) (Saltveit, 2003) (Valero et al., 2008).

Modification of the atmosphere inside the package by lowering $\mathrm{O} 2$ concentration and increasing $\mathrm{CO} 2$ concentration depends on the characteristics of the produce and thereforethe sort of the packaging film (Mahajan et al., 2007) (Mangaraj, Goswami and Mahajan, 2009). Investigations administered have shown that within a narrow range of $\mathrm{O} 2$ and $\mathrm{CO} 2$ concentrations and storage temperature, time period of the produce such as fruits and vegetables are often a maximum (Little and Taylor, 1982) Addition of various amounts of chitosan during cheese making,

(Gammariello et al., 2009) combined with modified atmosphere packaging (MAP) was wont to prolong the time period of stracciatella cheese Postharvest handling 
practices like harvesting, precooling, cleaning or disinfecting, sorting and grading, packaging, storage, and transporting played a crucial role in maintaining quality and increasing time period after harvest.

\section{Effect of different packaging materials on shelf life of sapota}

Packaging is defined as a mean or system by which a fresh produce or processed product will reach from the production middle to ultimate consumer in safe \& sound condition at an affordable price. packaging materials must be non-toxic and appropriate with the certain foods.

\section{The function of packaging}

To get together and fabricate into convenient component for handling. A properly designed produce container should contain, protect, and identify the produce, satisfying (MAP) Modification of the atmosphere within the package by reducing the oxygen content while increasing the levels of carbon dioxide and/or nitrogen has been shown to significantly extend the shelf-life of Sapota. (D. K. Antala1, et al., 2014) also conducted in sapota fruit storage by

Minimize level of $\mathrm{O}_{2}$ concentration and accelerating the level of $\mathrm{CO}_{2}$ consideration. Matured sapota fruits take place with the used of active (MAP) in $25 \mu$ and $40 \mu$ material like LDPE bags with $\mathrm{CO}_{2}$ consideration and stored in required temperature. Result stated that sapota fruit able to stored several days and maintain the quality standard of the fruit using with $110 \mathrm{C}$ in $25 \mu$ LDPE bags can maintained the quality standard and stored up to maximum 35 days and using $25 \mu$ LDPE bags with the help of gas application the shelf life of sapota fruit can maintain and also increase the shelf life about 49 days.
Similar research and study has been done in fig by Bouzo et al., (2012) fruits were stored at $2^{\circ} \mathrm{C}$ and were left unwrapped or wrapped with a $20 \mu \mathrm{m}$ polyethylene film in plastic trays. Dissimilar treatments were estimate: In all the treatments, the chromatographic profiles showed the presence of acetaldehyde, ethyl acetate, hexanal and ethanol. However, in unwrapped or control treatment there was a greater than ethyl acetate. film barriers used to reduce the transpiration rate of the product (Ullah et al., 2006).

Kalipatti el al., (2006) conducted the dis similar packaging materials T3 $(100 \mu$ LDPE) result the highest Organoleptic reported the highest TSS. Therefore $100 \mu$ LDPE shown advantageous compared to other materials packaging. (Ankagi Nikhil, 2007) Well matured sapota fruits of var. Cricket Ball. (T2) proved to be the best treatments according to results revealed and followed by $100 \mu \mathrm{LDPE}$ (T3) also reported improve the quality standard and storability of fruits the $75 \mu$ LDPE (T3) shows the lowest PLW.

Similar research and study different packaging has been done on other crops (Nath et al., 2012) An experiment was administrated on pear fruit (cv. 'Lagoon') Carry out dissimilar packaging materials to increase the shelf life of pear fruit with (LPDE, $0.0123 \mathrm{~mm}$ ) (PP, 0.02mm) (LLDPE, 0.0125 $\mathrm{mm})$ and high substances polyethylene (HDPE, $0.025 \mathrm{~mm}$ ) result shown different effect in physiological like colour index and chemical content like(TSS, ${ }^{\circ}$ Brix), decay loss (\%), firmness (kgf), and loss of vitamin c.

(Rajesh Kumar, 2000). Reported during the ripening of fruits a changed was occur in physiological, under dissimilar packaging and material like newspaper, typewriter paper, polyethylene bags shown different effect on physical standard and even in chemical quality which included TSS and well as 
acidity content of the fruit (Deka et al., 2012) Supported the packaging material, carry out the decent packaging materials with the help of films product obtained for the (MAP) packaging of Sapota fruit. This experiment conducted, the addition of chitosan into cheese making, combined with either coating or active coating (lysozyme and ethylenediamine tetra acetic acid, disodium salt) and MAP (modified atmosphere packaging) was used to prolong the period of time.

\section{Effect of Ga3 and wax coating on shelf life of sapota}

Coatings effect in physiology and maintained the pores on the produce skin, reducing fruit water loss. Wax is usually utilized in many fruits such citrus, tomato, bell pepper, and cucumber to enhance fruit appearance and reduce transpiration; however, the effect of the wax on reducing fruit transpiration is limited about $30 \%$ reduction Coatings with containing $2 \%$ or $4 \%$ hydroxy propylcellulose significantly slowed softening an average of $35 \%$ or $45 \%$, and contrast again with uncoated fruit.

$10 \%$ to $30 \%$ with A $5 \%$ carnauba formulation slowed softening and resulted most successful at reducing weight loss conducted by (McGuire RG, Hallman GJ 1995) and similarly research was conduct on sapota fruit by (Joslin Menezes et al., 2016) 2\% with 2 min dipping pectin edible coating time coated with sodium alginate in sapota fruit showed significant reduction in changes within the chemical parameters like weight loss, total soluble solids, acidity, colour, ascorbic acid, firmness and $\mathrm{pH}$ at refrigerated temperature storage $\left(4 \pm 1^{\circ} \mathrm{C}\right) .2$.

Maintaining the organoleptic properties of the fruits upto 30 days with polysaccharide coating with 2 min dipping time was effective to maintained of the fruit.
Different effect of polypropylene, LDPE, HDPE, shrink, cling, on shelf life of sapota

Geason et al., (1991) reported that healthy mature pears were packed and maintain in low density polyethylene (LDPE) films retarded and shown the soften on flesh pear fruit and also stated the increase in spoilage of pear fruits by (Sandhu and Singh, 2000).

Bhupinder Sing et al., (2005) stated minimum physiological loss in weight, decay loss and maximum pulp: peel ratio, fruit shape index was observed in T3 as compared to other treatments. By applying T3 (shrink), the period of time of fruit is increased for several time period at optimized temperatures (13$\left.15^{\circ} \mathrm{C}\right)$.

Similar research and study has been done on other crop by (Pal et al., 2004) Revealed that Guava fruits of cv. L-49 were wrapping using $9 \mu$ LLDPE film result shown successfully stored up to 12 days at diffusive and in evaporative cool chamber18 days with insignificant loss in vitamin $\mathrm{C}$ content. (Sudhir Pratap et al., 2017). The investigation was carried out with five different packaging substances T1 (LDPE), T2 (HDPE), T3 (Shrink), T4 and T5 (Cling) for expand the shelf life of sapota at dissimilar temperature and ambient temperature. The effect of packaging material on physiological loss in weight, decay loss, pulp: peel ratio, fruit length, fruit width, and fruit shape index, and according based on research by Kalipatti et al., 2006) Low-density polyethylene T3 $(100 \mu$ LDPE) result show positive effect in chemical content as well as maintain the firmnesss and in Organoleptic score positive effect, TSS compared to other experiment conducts (Mahajan et al., 2014). The shrink film was reported and support reduced the loss in of fruit weight, complexion and maintained the quality standard and even chemical content like TSS, vitamin content 
and also during shelf-life higher than compared to unwrapped control fruits.

In conclusion the paper is to establish the potential of the utilization of Sapota to extend the sheld life with maximum quality which give more time to transport and sell your products and reduces inventory shrinkage due to spoilage, which translates to lower costs and more goods making it to consumers.

Since the use of (MAP) Modification of the atmosphere and other packaging material like The packaging films used LDPE, HDPE, Shrinkfilm, Polypropylene and Cling are used to maintained the quality of the fruit among this materials polypropylene LDPE,HDPE and Shrink film reported common suitable and successful to extend the shelf life and maintain of the fruit quality standard and prolong the appearance of Sapota fruit with the help of this material packaging can prolong and extend the shelf life of fruit secure the losses hold out marketing value.

\section{References}

Ankalagi nikhil, Krishna Bukya, Baknika. K. and Monin manisha ch. (2017). Department of Post Harvest Technology of Horticultural Crops, Faculty of Horticulture, Bidhan Chandra Krishi Viswavidyalaya, Mohanpur, Nadia, 741252.

Antala, D. K., R. M. Satasiya, P. D. Akabari, J. V. Bhuva, R. A. Gupta and Chauhan, P. M. (2016). Effect of Modified Atmosphere Packaging on Shelf Life of Sapota College of Agricultural Engineering\& Technology, Junagadh Agricultural University, Junagadh-362 001 (Gujarat), India.

AOAC (1990) Associate of official Agricultural chemists, Official methods of Analysis, AOAC, Washington DC.

Aradhya, S. M. and Policegourd, R. S., Pre and post harvest technology of sapota. Indian Food Packer, 60(1): 63-71 (2006).

Ingle, G.S. Khedhkar, D. M. and Dabhade, R. S. (1981). Ripening studies in sapota fruit (Achras sapota L). Indian Food Packer, 35: 42-45.

Joshua, P. and Sathiamoorthy, S. (1993). Storage of sapota fruits in polyethylene bags. South Indian Horticulture, 41(6): 368-369.

Joslin Menezes, K.A. Athmaselvi. (2016). Polysaccharide based edible coating on sapota fruit Department of Food Process Engineering, School of Bioengineering, SRM University, Kattankulathur, Chennai - 603203, Tamil Nadu, India.

Kanetis, L. Förster, H. and Adaskaveg, J. E. (2007). Comparative efficacy of the new postharvest fungicides azoxystrobin, fludioxonil, and pyrimethanil for managing citrus green mold. Plant Dis. 91:1502-1511.

Kariyanna, K. M., Bojappa and Reddy, T. V. (1993). Influence of some Harvest Treatments on ripening and quality of sapota fruits. Golden Jubilee Symposium, Horticultural Research on Changing Scenario, Abstract, p: 300. (Banglore, May 24-28, 1993).

Kumar, J., Sharma, R. K. and Singh, R. (2000). The effect of different methods of packing on the shelf life of kinnow. Haryana Journal of Horticultural Sciences, 29(3/4): 202-203.

Little, C. R. and H. J. Taylor (1982). Effect of initial oxygen stress treatments in low oxygen at modified atmosphere storage. J. Amer. Soc. Hort. Sci., 107: 320-323.

Mahajan, B. V. C., W. S. Dhillon, Mahesh Kumar, and Bikramjit Singh,(2014). Effect of different packaging films on shelf life and quality of peach under super and ordinary market conditions, Punjab Horticultural Postharvest Technology Centre, Punjab Agricultural 
University, Ludhiana, 141004 Punjab India.

McGuire RG, Hallman GJ (1995) Coating guavas with cellulose or carnuba based emulsions interferes with post harvest ripening. Horticult Sci 30(2): 294-295.

Nath, Bidyut C. Deka; Akath Singh; R. K. Patel; D. Paul; L. K. Misra and H. Ojha, (2012). Extension of shelf life of pear fruits using different packaging materials J Food Sci Technol., DOI 10.1007/s13197-011-0305-4.

NHB (2011) Indian horticulture database. Nat HortMission Government of India, Gurgaon. Chundawat BS, Bhuva HP (1982).
Pal, R.K. Ahmad, M.S., Roy, S.K., Singh, M., (2004). Influence of storage environment, surface coating and individual shrink wrapping on quality assurance of guava fruits. Plant Foods Hum. Nutrition. 59, 67-72

Panse, V. G. and P. V. Sukhtme (1985). Statistical methods for Agricultural workers. Indian Council of Agricultural Research, New Delhi.

Pekmezei M, Erkan M, Demirkol A (1995) The effect of harvest time and different postharvest applications on the storage of valencia oranges. Acta Horticult 398: 276-284

\section{How to cite this article:}

Joseph K. Beikhosia and Vijaya Rawat. 2020. To Study the Effects of Different Packaging Materials on Shelf Life of Sapota - A Review. Int.J.Curr.Microbiol.App.Sci. 9(11): 2310-2315. doi: https://doi.org/10.20546/ijcmas.2020.911.277 